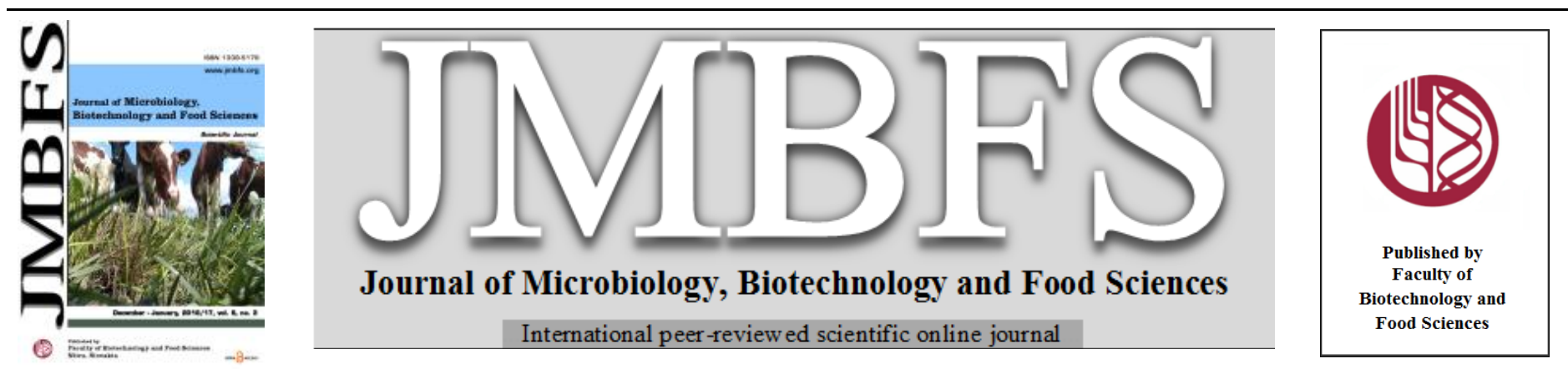

\title{
DIESEL BIOTREATMENT COMPETENCE OF INDIGENOUS METHYLPARATHION DEGRADING BACTERIAL STRAIN OF PSEUDOMONAS AERUGINOSA DOU
}

\author{
Krishnaswamy Rathinam Usharani ${ }^{1,2}$, Perumalsamy Lakshmanaperumalsamy ${ }^{1}$ \\ $\operatorname{Address}(e s):$ \\ ${ }^{1}$ Division of Environmental Microbiology, Department of Environmental Sciences, Bharathiar University, TN, India. \\ ${ }^{2}$ Department of Environmental Science, School of Energy, Environment and Earth Sciences, Central University of Kerala, India.
}

*Corresponding author: usharaniks2003@yahoo.com

doi: $10.15414 / j m b f s .2016 / 17.6 .3 .878-885$

\section{ARTICLE INFO}

Received 13.8. 2015

Revised 3. 9. 2016

Accepted 19. 8. 2016

Published 1. 12. 2016

Regular article OPEN $\partial_{\text {ACCESS }}$

\begin{abstract}
Pseudomonas aeruginosa methylparathion degrading bacterial strain previously isolated and identified in our lab was subjected to confirm their ability to diesel oil degradation in synthetic wastewater containing diesel oil (10\% v/v). They are cultured in modified mineral salts agar medium with diesel oil as the sole source of carbon. They were able to grow and distinguish in 7 days of incubation. Biosurfactant was produced in the medium and its effect was detected using emulsification activity, growth estimation and gravimetric analysis as an indicator for this process. Factors affecting hydrocarbon utilization by this isolate were $\mathrm{pH}$, temperature, salt concentration and agitation along with glucose, peptone, phosphate and nitrate concentrations. Gravimetric and FTIR analysis showed that the strain was able to degrade complex hydrocarbon chains to simple ones. The optimum conditions of various factors showed that, neutral $\mathrm{pH}$, with temperature of $32^{\circ} \mathrm{C}$, and agitation rate of $150 \mathrm{rpm}$ gave the optimum conditions to accelerate diesel oil degradations, while additional nutrients of glucose $(1 \mathrm{mg} / \mathrm{l})$, peptone $(5 \mathrm{mg} / \mathrm{l})$, sodium nitrate $(2 \mathrm{mg} / \mathrm{l})$, phosphate $(7 \mathrm{mg} / \mathrm{l})$ and sodium chloride $(3$ $\mathrm{mg} / \mathrm{l}$ ) enhanced optimum effect on the bioprocess. The bacterial strain of indigenous pure monoculture having the degradative potential of xenobiotic compounds of various pollutants includes diesel oil as well as methylparathion pesticide practically. The main conclusion is that Pseudomonas aeruginosa dou-1 strain can be able to degrade complex hydrocarbons and make it an ideal applicant in bioremediation.
\end{abstract}

\section{INTRODUCTION}

Environmental pollution with petroleum and petroleum products (complex mixture of hydrocarbons) has been recognized as one of the most serious current problems, hydrocarbons may reach the water table before becoming immobilized in the soil. They spread horizontally on the ground water surface and continue to partition into ground water, soil pore space, air and to the surface of soil particles. Oil contamination of soil and water from industrial sources and other activities are producing ecological disasters and addressing public concerns (Che, 2002). India's oil and gas sectors meet around $42 \%$ of the country's primary energy demand and contribute over $15 \%$ to the gross domestic product. Oil spill accidents are very common in the areas near the seashore because of shipping of oil tankers and bursting of oil supply pipelines. Recently in India, mumbai-urban oil spill through the pipeline bursting witnessed about 600 metric tons spillage of crude oil which caused a widespread mortality of sea animals. The contamination of soil and groundwater by hazardous chemicals has become a major concern due to the associated risks to human health and the environment (Ghosh and Tick, 2013).

Petroleum-based products are the major source of energy for industry and daily life. Petroleum products such as engine oil, petrol, diesel and kerosene are used daily in various forms in mechanic workshops. Petroleum hydrocarbons composed of complicated mixtures of non-aqueous and hydrophobic components such as n-alkane, aromatic, resins and asphaltenes. Oil contamination with petroleum hydrocarbons has caused critical environmental and health defects and increasing attention has been paid for developing and implementing innovative technology for cleaning up this contamination (Yeung, 1997). Diesel, a derivative of Petroleum is one of the major pollutants of water and soil. In areas where oil refineries are present, air, water and soil resources have become contaminated with oil and its by-products namely diesel. Diesel oil, which is one of the major products of crude oil, constitutes a major source of pollution in our environment. Transportation through the railways and roadways causes organic and inorganic contamination. Broken and corroded oil pipelines significantly contribute to oil pollution on a large and rapidly increasing scale. Due to the adverse impact of these chemicals on human health and environment, they are classified as priority environmental pollutants by the US Environmental Protection Agency (1996). The numbers of spills that have dumped millions of gallons of crude oil into the environment have been steadily increasing over the past decade. This can lead to disastrous consequences. Therefore the pollutants need to be removed or destroyed from the environment.

An array of procedures has been developed including physical, chemical and biological techniques. Among these procedures, bioremediation is currently used alone or associated with physicochemical procedures. Biological methods of rehabilitation of polluted sites represent an interesting alternative. These techniques are based on the microorganism's capacities to degrade petroleum compounds (Harayama, 1999). Bioremediation has become an alternative way to remedy oil polluted sites, where the addition of specific microorganism (bacteria) or enhancement of microorganism already present can improve biodegradation efficiency (Hagwell et al., 1992). These microorganisms can degrade a wide range of target constituents present in oil sludge (Barathi and Vasudevan, 2001; Mishra et al., 2001).

The study of petroleum degrading bacteria therefore becomes very important in deal with problems of oil and petroleum based pollutions. In this study, Pseudomonas aeruginosa mehtylparathion degrading bacterial strain previously identified and stored in our lab was subjected to diesel oil degradation in synthetic wastewater containing diesel oil.

\section{MATERIAL AND METHODS}

The mehtylparathion degrading Pseudomonas aeruginosa bacterial strain previously identified and stored in the lab was used for diesel oil degradation. Diesel oil used in this study was refined diesel oil commercially available, which was purchased from local petrol station. 


\section{Morphological and Biochemical Characterization}

Gram staining revealed that the morphological characters of the isolated bacterial strains. Spore staining shows weather the organism is spore producing or not Motility test can determine the organism which is motile or non-motile. Catalase test was performed to check the ability of the isolated strains to degrade hydrogen peroxide and Oxidase test for the detection of presence of cytochrome oxidase enzyme. IMViC test is performed for the identification of the organisms. Carbohydrate utilization tests revealed that the ability of the isolated strains in fermentation of sugars like glucose, lactose, sucrose and mannitol. The genus and species of Pseduomonas aeruginosa was identified and confirmed by Pseudomonas agar medium and King's A medium. The identification was done by on the basis of morphological and biochemical characteristics as per Bergeys Manual of Systemic Bacteriology (Holt et al., 1994).

\section{Screening the capability of diesel oil utilization by potential methylparathion degrading bacterial strain}

The screening of the diesel oil degrading bacteria was done by inoculating $1 \mathrm{~m}$ of pure culture (Pseudomonas aeruginosa) in diesel oil containing nutrient broth (NB) and incubated for 21 days at $35^{\circ} \mathrm{C}$ on rotary shaker at $150 \mathrm{rpm}$. After growth in NB, serial dilutions (up to $10^{-5}$ ) were made and $100 \mu 1$ of the liquid was surface spread on nutrient agar plates containing diesel oil $(1 \% \mathrm{v} / \mathrm{v})$ and plates were incubated at $35^{\circ} \mathrm{C}$ for $72 \mathrm{~h}$. A colony was picked and streaked on nutrient agar plates with increased concentration of diesel oil (up to $10 \%$ ). Out of these the best grown isolates were selected and were maintained in modified mineral salts (MMS) agar medium $\left(\mathrm{K}_{2} \mathrm{HPO}_{4} 7.0 \mathrm{mg} / \mathrm{l} ; \mathrm{NaNO}_{3} 2.0 \mathrm{mg} / \mathrm{l} ; \mathrm{NaCl} 3.0 \mathrm{mg} / \mathrm{l}\right.$ Peptone5.0mg/l; glucose $1.0 \mathrm{mg} / \mathrm{l}$; agar $22.0 \mathrm{mg} / \mathrm{l}$; Distilled water $1000 \mathrm{ml}$; pH$7.0 \pm 0.2$ ) and stored at $4{ }^{\circ} \mathrm{C}$ for further work.

\section{Halo plate diffusion assay}

Growth on diesel was determined by halo plate diffusion assay by Bushnell Hass (BH) agar medium (Geetha et al., 2013 and Saadoun, 2002). Colonies of the different bacterial isolates were transferred into $50 \mathrm{ml} \mathrm{BH}$ Medium (Leadbetter, Foster, 1958), supplemented with $10 \%$ (v/v) diesel oil solutions, filter sterilized through $0.45 \mu$ membranes and incubated at $35^{\circ} \mathrm{C}$ in a water bath shaker at 150 rpm for 9 days. Bacterial growth was determined at intervals by measuring the optical density $\left(\mathrm{OD}_{600} \mathrm{~nm}\right)$. The test to detect the biodegradation of diesel was studied by a monooxygenase biodegradation pathway (Jacob et al.,1983). The test was performed at $28^{\circ} \mathrm{C}$ in a glass test tubes containing; $20 \mu 1$ of $0.05 \mathrm{~mol} / \mathrm{l}$ 2,6- dichlorophenolindophenol (DCPIP) (Himedia, India); $30 \mu 1$ of $0.05 \mathrm{~mol} / 15$ methyl-phenazinium methylsulphate (5-MPMS); $25 \mu \mathrm{l} 0 \mathrm{f} 0.1 \%$ (v/v) diesel; $5 \mu 1$ of $0.15 \mathrm{M}$ NAD solution and $25 \mu \mathrm{l}$ of pre-washed bacterial cells. Change in color was visually compared with different controls: no diesel (substrate); no NAD+; no cells and heat-killed cells. The reaction was monitored up to 12 hours with intermittent observations (Geetha et al., 2013).

\section{Optimization of growth conditions}

The initial enrichment cultures were established in synthetic wastewater containing mineral salts medium amended with the diesel oil as the sole source of carbon and energy. The optimum temperature, agitation, $\mathrm{pH}$ and salinity concentration, glucose, peptone, nitrogen, nitrate, phosphate and diesel concentrations for the growth of the bacterial strains were determined. In order to optimize the growth conditions, potential bacterial strains $(1 \% \mathrm{v} / \mathrm{v})$ was grown in a conical flask containing $100 \mathrm{ml}$ MMSM and $1 \%(\mathrm{v} / \mathrm{v})$ diesel at $35^{\circ} \mathrm{C}$ for $24 \mathrm{hr}$ and it provides as the inoculum. The MMSM containing flaks were inoculated with $1 \mathrm{ml}$ of inoculum with $0.1 \mathrm{OD}$ culture and incubated the flasks at $35^{\circ} \mathrm{C}$ for 9 days. After every $24 \mathrm{hr}$ the treated culture medium was analysed for the diese degradation up to 9 days. The growth in terms of optical density (OD $600 \mathrm{~nm}$ ) value was determined by turbidity measurement using UV-Vis spectrophotometer (Shimadzu - UV- 3600, Japan).

\section{Effect of different factors on diesel oil utilization}

Different factors were tested for optimization of diesel utilization. These were $\mathrm{pH}, \mathrm{NaCl}$ concentration, temperature, time and agitation (Satpute et al., 2008).

\section{Effect of diesel oil concentration}

The concentration of diesel oil as hydrocarbon source (up to $10 \% \mathrm{v} / \mathrm{v}$ ) was studied to determine the effect of diesel oil on the growth of bacteria.

\section{Effect of Temperatures on growth.}

Temperature is one of the most important physical factors affecting bacterial growth. The potential bacterial strain inoculated MMS medium containing flasks along with control were incubated for 9 days at different temperatures $\left(28^{\circ} \mathrm{C}\right.$, $30^{\circ} \mathrm{C}, 35^{\circ} \mathrm{C}$ and $40^{\circ} \mathrm{C}$ ) in a rotary shaker at $150 \mathrm{rpm}$. The presence or absence of growth of the cultures was observed after every $24 \mathrm{hr}$ of incubation. The degree of growth was observed at wavelength of $600 \mathrm{~nm}$ using spectrophotometer.

\section{Effect of agitation on growth}

The effect of agitation on the growth of bacteria in MMSM was varied at different rpm $(100,120,150$ and $170 \mathrm{rpm})$ using incubator shaker and the optimum growth was monitored.

\section{Effect of $\mathrm{pH}$ on growth}

To study the effect of $\mathrm{pH}$ on the growth of bacteria, the $\mathrm{pH}$ of the MMSM was varied $(\mathrm{pH} 5,6,7,8,9)$ using $1 \mathrm{~N} \mathrm{HCl}$ and $1 \mathrm{~N} \mathrm{NaOH}$ and the growth was continuously monitored. The $\mathrm{pH}$ was adjusted and monitored using $\mathrm{pH}$ meter (Fisher Accruement $\mathrm{pH}$ meter).

\section{Effect of salt concentrations on growth.}

The effect of salt concentration on the growth of the bacteria was studied by growing the culture in MMSM with different salt concentration $(4 \%, 8 \%, 12 \%$, $16 \%$ and $20 \%$ of $\mathrm{NaCl}$ ). One $\mathrm{ml}$ of the potential culture strain was added into the MMSM with different salt concentration and incubated for $24-48$ hours at $35^{\circ} \mathrm{C}$ in a rotary shaker at $150 \mathrm{rpm}$.

\section{Effect of carbon source and glucose concentration on growth}

The effect of carbon source was investigated by growing the culture in MMSM supplemented with different carbon sources includes glucose, sucrose and fructose. Glucose was selected as the source which can best enhance the growth of bacteria. The concentration of the glucose was varied $(0.5 \%, 1 \%, 2 \%, 3 \%$ $\mathrm{w} / \mathrm{v})$ to probe the influence of concentration of carbon on the growth of bacteria.

\section{Effect of nitrogen source and its concentration}

The effect of nitrogen source was investigated by growing the culture in MMSM supplemented with different nitrogen sources; urea, ammonium nitrate, sodium nitrate. Sodium nitrate was selected as the nitrogen source which can best enhance the growth of the bacteria. The concentration of the sodium nitrate was varied $(0.5 \%, 1 \%, 2 \%, 3 \% \mathrm{w} / \mathrm{v})$ to probe the influence of concentration of nitrogen on the growth of bacteria. The effect of peptone concentration was also studied with various concentration of peptone $(0.5,1-6 \mathrm{mg} / \mathrm{l})$ to investigate the growth of bacteria.

\section{Screening of oil degrading Biosurfactant producing bacterial strains}

The isolates of the bacteria was screened for production of oil degrading biosurfactant. The screening was carried out by the following methods. Biosurfactant production and diesel degradation capabilities of the isolates were determined by using drop collapse method, oil spread method and measurement of emulsification index $\left(\mathbf{E}_{24}\right)$. The determination of diesel oil degradation ability of the selected potential bacterial strain was done by gravimetric analysis and FTIR analysis.

\section{Drop collapse method}

Biosurfactant production was screened using the qualitative drop collapse test $2 \mu \mathrm{l}$ of diesel was added to 96 well micro-titre plates. The plates were equilibrated for 1 hour at $30^{\circ} \mathrm{C}$ and $5 \mu \mathrm{l}$ of the respective culture supernatant obtained was added to the surface of the oil in the well. The shape of the drop on the oil surface was observed for 1 minute. If the culture supernatant makes the drop collapse, it indicated positive result for biosurfactant presence and if the drop remained as such it indicated negative result (Bodour et al., 2003).

\section{Oil spread method}

The petridish base was filled with $50 \mathrm{ml}$ of distilled water. On the water surface, $20 \mu \mathrm{l}$ of diesel and $10 \mu \mathrm{l}$ of culture were added respectively. The culture was introduced at different spots on the diesel which is coated on the water surface. The occurrence of a clear zone was an indicator of positive result (Morikawa et al., 2000).

\section{Emulsification Index $\left(\mathbf{E}_{24}\right)$}

The emulsifying capacity was evaluated by an emulsification index. The $E_{24}$ of the culture samples was determined by adding $2 \mathrm{ml}$ of diesel and $2 \mathrm{ml}$ of the inoculum in a test tube and it was shaken for 2 minutes. Then, water and diesel were added and shaken for 2 minutes to obtain maximum emulsification and allowed to stand for 24 hours. This was taken as control (Desai and Banat, 1997). 
The percentage of the $\mathrm{E}_{24}$ index is calculated by the following formula:

eqn.[1]

$$
E_{24}=\frac{\text { Height of the emulsified layer }(\mathrm{cm} .)}{\text { Total height of the column }(\mathrm{cm} .)} \times 100
$$

\section{Analytical Characterization}

\section{Batch degradation of diesel oil by potential bacterial strains in SWW}

Biodegradation of diesel oil using Pseudomonas aeruginosa dou-1 was evaluated in synthetic wastewater. The potential bacterial strains at the log phase overnight cultures with 1 O.D (at $600 \mathrm{~nm}$ ) were transferred to $250 \mathrm{ml}$ conical flasks containing $100 \mathrm{ml}$ of sterile defined modified mineral salts medium with $10 \%$ diesel oil in triplicates. All flasks were incubated at $32^{\circ} \mathrm{C}$ in a rotary shaker at 150 rpm for 10 days. The uninoculated medium containing $10 \%$ diesel oil and MMSM broth serves as control. At $24 \mathrm{hr}$ intervals, sets of flasks were used for the extraction of residual oil. Whole sample contained in the individual flasks were extracted at initial 0 time, and every $24 \mathrm{hrs}$ up to 10 days for the purpose of measuring residual concentration (Bishnoi et al., 2009). The total hydrocarbons in the treatments were determined gravimetrically.

\section{Gravimetric analysis}

The oil degradation was quantified by measuring the oil recovery after 16 th days of incubation using the gravimetric analysis (Marquez-Rocha et al., 2001). The amount of oil in wastewater was estimated using the Gravimetric method. About $4 \mathrm{ml}$ of treated culture sample was taken from flask. Petroleum ether and acetone were taken in the ratio $1: 1$ and was mixed with the sample in a separating funnel The mixture was shaken for about 45 minutes and then was left undisturbed for about 10 minutes. The upper solvent along with oil was separated from the lower extract. The solvent with the oil layer was then kept in the hot air oven at about $50^{\circ} \mathrm{C}$ until the solvent gets evaporated. After the complete evaporation, the oil residue obtained was weighed and taken as the gravimetric value for further calculation. Analysis of sample before and after treatment was done using this Gravimetric method.

The percentage of diesel oil degraded was determined from the following formula:

eqn.[2]

$$
\text { PDOD }=\frac{\text { Weight of diesel oil degraded }}{\text { Weight of diesel oil present originally }} \times 100
$$

Where,

PDOD $=$ Percenetage of diesel oil degradated,

the weight of diesel oil degraded $=$ (original weight of diesel oil $)-($ weight of residual diesel oil obtained after evaporating the extractant).

Weight of residual oil $=($ Weight of beaker containing extracted oil $)-($ Weight of empty beaker).

\section{FT-IR Analysis}

After 7 days of growth, cell biomass was removed by centrifugation of broth culture at $10,000 \mathrm{rpm}$ for 15 minutes. Then the supernatant was precipitated overnight with ice cooled ethanol. The precipitated medium was centrifuged and the pellet was collected, dialyzed against distilled water for 24 hours and then lyophilized. A lyophilized sample was ground with potassium bromide $(\mathrm{KBr})$ powder and pressed with $7,500 \mathrm{~kg}$ for 30 s to obtain a translucent pellet. The infrared spectra were recorded on an FT-IR system (Perkin Elmer 783, Germany) within the range of $400-4,000 \mathrm{~cm}^{-1}$ wave number. A $\mathrm{KBr}$ pellet was used as background.

\section{RESULTS AND DISCUSSION}

\section{Morphology and Biochemical Characterization}

The selective potential bacterial strain was analyzed taxonomically. The colony morphology of the strain was abundant, thin, white growth with medium turning green, earthy odour and rod shape. The strain was found to be Gram negative and rod shaped bacterium (Figure. 1). Based on the biochemical characteristics, the selected potential bacterial strain was identified as Pseudomonas aeruginosa dou-1(Table. 1).

Screening the competence of diesel oil utilization by potential methylparathion degrading bacterial strain (Pseudomonas aeruginosa dou-1).

The bacterial strain used for the biotreatment process was Pseudomonas aeruginosa dou-1 (Table.1 and Figure 1), which is a methylparathion degrading bacterial strain previously identified according to Bergy's manumal of determinative bacteriology (Holt et al., 1994; Cappuccino and Sherman, 2010) stored in the lab was subjected to diesel oil degradation in synthetic wastewater containing diesel oil at $10 \%$ (MMSM). The bacterial strain which was found to persist and grow under high diesel oil concentration was screened from this study and named as Pseudomonas aeruginosa dou-1. In Figure.1, there was not much difference between the colony forming units found in nutrient agar (NA-36 x10-2 $\mathrm{CFU} / \mathrm{ml}$ ) was) medium when compared to modified mineral salts agar medium (MMSM- 34 x10-2 CFU/ml)

\begin{tabular}{|c|c|}
\hline Biochemical Tests & Characters \\
\hline $\begin{array}{l}\text { Colony morphology on } \\
\text { Nutrient Agar medium }\end{array}$ & $\begin{array}{l}\text { Abundant, thin, white growth with } \\
\text { medium turning green, earthy odour }\end{array}$ \\
\hline Gram stain & Negative, Rod shaped \\
\hline Spore & Negative \\
\hline Motility & Positive \\
\hline Catalase & Positive \\
\hline Oxidase & Positive \\
\hline Indole & Positive \\
\hline Methyl Red & Positive \\
\hline Voges Proskaur & Positive \\
\hline Citrate & Positive \\
\hline Nitrate & Positive \\
\hline Glucose & Positive \\
\hline Lactose & Negative \\
\hline Sucrose & Negative \\
\hline Mannitol & Negative \\
\hline Rhamnose & Negative \\
\hline $\mathrm{H}_{2} \mathrm{~S}$ production & Negative \\
\hline Gelatine liquefaction & Positive \\
\hline Casein hydrolysis & Negative \\
\hline Lipid hydrolysis & Positive \\
\hline Starch hydrolysis & Negative \\
\hline Growth: at $\left(28-40^{\circ} \mathrm{C}\right)$ & Positive \\
\hline at (pH 5-8) & Positive \\
\hline at (100-170 rpm) & Positive \\
\hline $\begin{array}{l}\text { Growth in Selective medium } \\
\text { Cetrimide agar medium } \\
\text { Pigment production: }\end{array}$ & Positive \\
\hline $\begin{array}{l}\text { Pseudomonas agar medium and } \\
\text { King's A medium. }\end{array}$ & Positive \\
\hline
\end{tabular}

Table 1 Identification of potential bacterial strain of biosurfactant activity

King's A medium.

Identified Bacterial strain

Pseudomonas aeruginosa dou-1

Hole-plate diffusion test using diesel as a carbon source showed bacterial growth around the holes containing the diesel. Growth of hydrocarbon degrading bacteria using different concentration of hydrocarbons as carbon source was analysed. The bacterial growth was observed in different concentration of hydrocarbons upto $10 \%$. The potent hydrocarbon degrading isolate (based on hole-plate diffusion method) were selected for the diesel degradation assay, by a monooxygenase biodegradation pathway. The test is based on the following reactions (Geetha et al., 2013).

Ethanol + nicotinamide adenine dinucleotide $(\mathrm{NAD}+)$

alcohol dehydrogenase

acetaldehy de $+\mathrm{NAD}++\mathrm{H}+$

$\mathrm{NAD}++\mathrm{H}++2$, 6-dichlorophenolindophenol(DCPIP) [oxidized, blue]

5-methyl-phenazinium methylsulphate

$\mathrm{NAD}++2,6$-DCPIP [reduced, yellow] 
But while considering the economic feasibility and applicability in wastewater treatment, the MMS medium was selected for further biotreatment study. The isolates grew maximally on the diesel substrate when supplied as the sole source of carbon and energy. In a similar research by Rahman et al. (2002), the total viable count method was used to confirm the potential of different kind of bacteria utilizing hydrocarbon. This technique was used in several studies to show the ability of bacteria utilizing hydrocarons (Emtiazi and Shakarami, 2004)
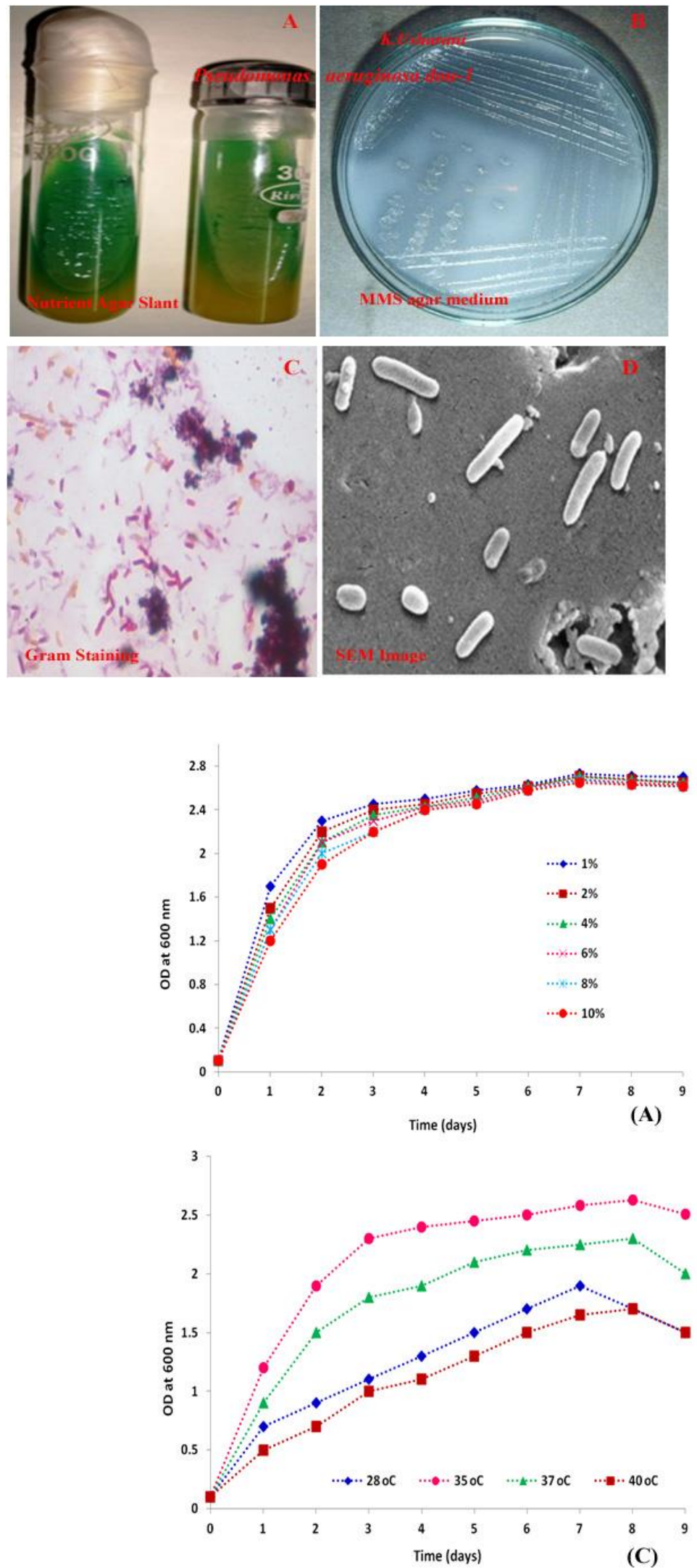

Figure 1 Identified potential bacterial strain of Pseudomonas aeruginosa dou-1 (A) on NA slant (B) on MMS agar medium (C) Gram Staining (D) SEM Image

\section{Optimization of growth conditions}

Effect of diesel oil with respect to time on the growth of selected bacterial strain (Pseudomonas aeruginosa dou-1)

The effect of different concentration of diesel oil $(1,2,4,6,8$ and $10 \%)$ on the growth of potential bacterial strain was studied. The bacterial strain Pseudomonas aeruginosa dou-1 showed an increase in cellular density with respect to growth tolerance occurring at maximum $10 \%(\mathrm{v} / \mathrm{v})$ of diesel concentration (Figure.2A). Cell density considerably reduced at diesel concentrations higher than this. The selected bacterial strain Pseudomonas aeruginosa dou-1 was able to tolerate high diesel concentration; this suggests that the strain is a better applicant for diesel biodegradation. Biodegradation studies on diesel are carried out using diesel concentrations ranging from 0.5 to $1.5 \%$ (Mukherji et al., 2004; Hong et al., 2005; Lee et al., 2006; Ueno et al., 2007) Degradation at a much higher concentration $(6 \% \mathrm{v} / \mathrm{v}$ diesel) has been reported but degradation requires glucose $(0.2 \% \mathrm{w} / \mathrm{v})$ and yeast extract $(0.1 \% \mathrm{w} / \mathrm{v})($ Kwapisz et al., 2008). Diesel is essential as a carbon source but it can be toxic to microorganisms due to the solvent effects of diesel that could obliterate cell membrane (Shukor et al., 2009).

\section{Effect of agitation with respect to time on the growth of bacteria}

The effect of different rate of agitation (rpm) on diesel degradation from the oil contaminated wastewater was studied. The bacterial strain Pseudomonas aeruginosa dou-1 showed optimal growth at $150 \mathrm{rpm}$ (Figure. 2B).

Figure 2 Effect of initial diesel oil concentration, agitation, temperature and $\mathrm{pH}$ on the growth of Pseudomonas aeruginosa dou-1

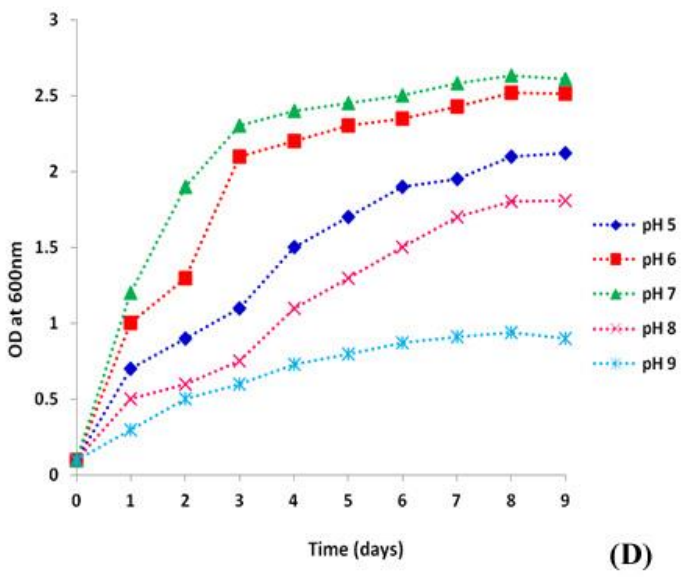



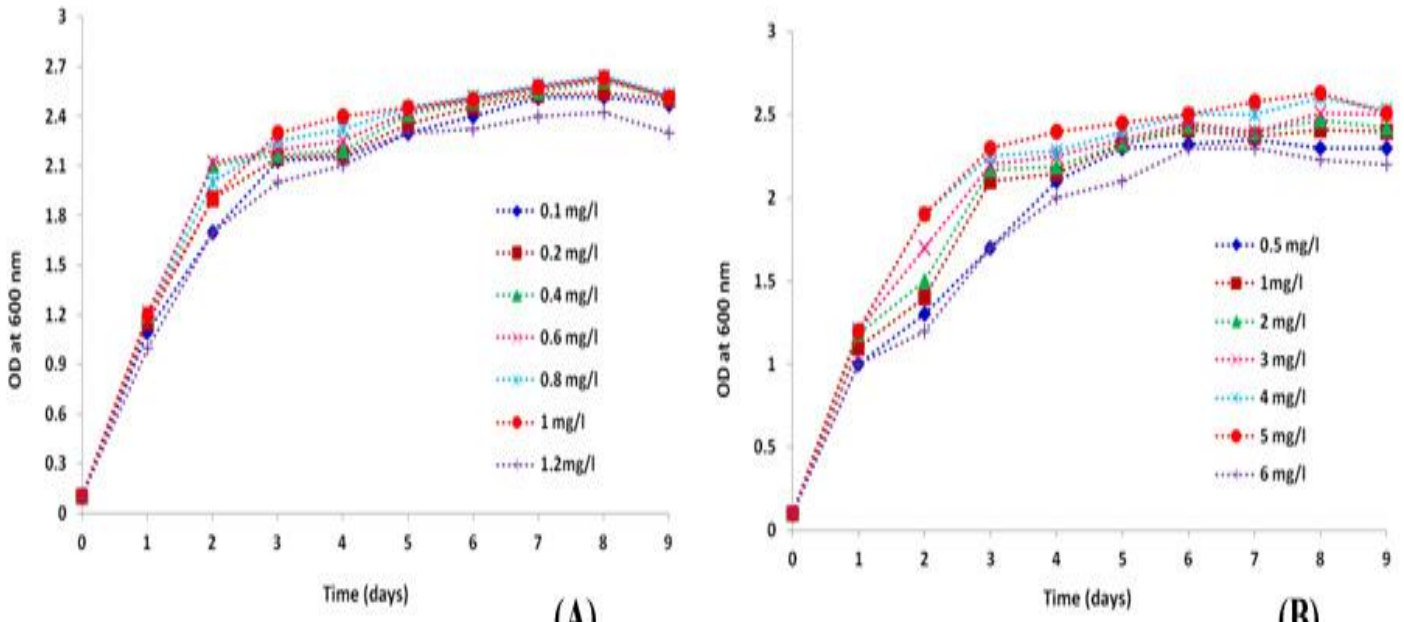

(A)
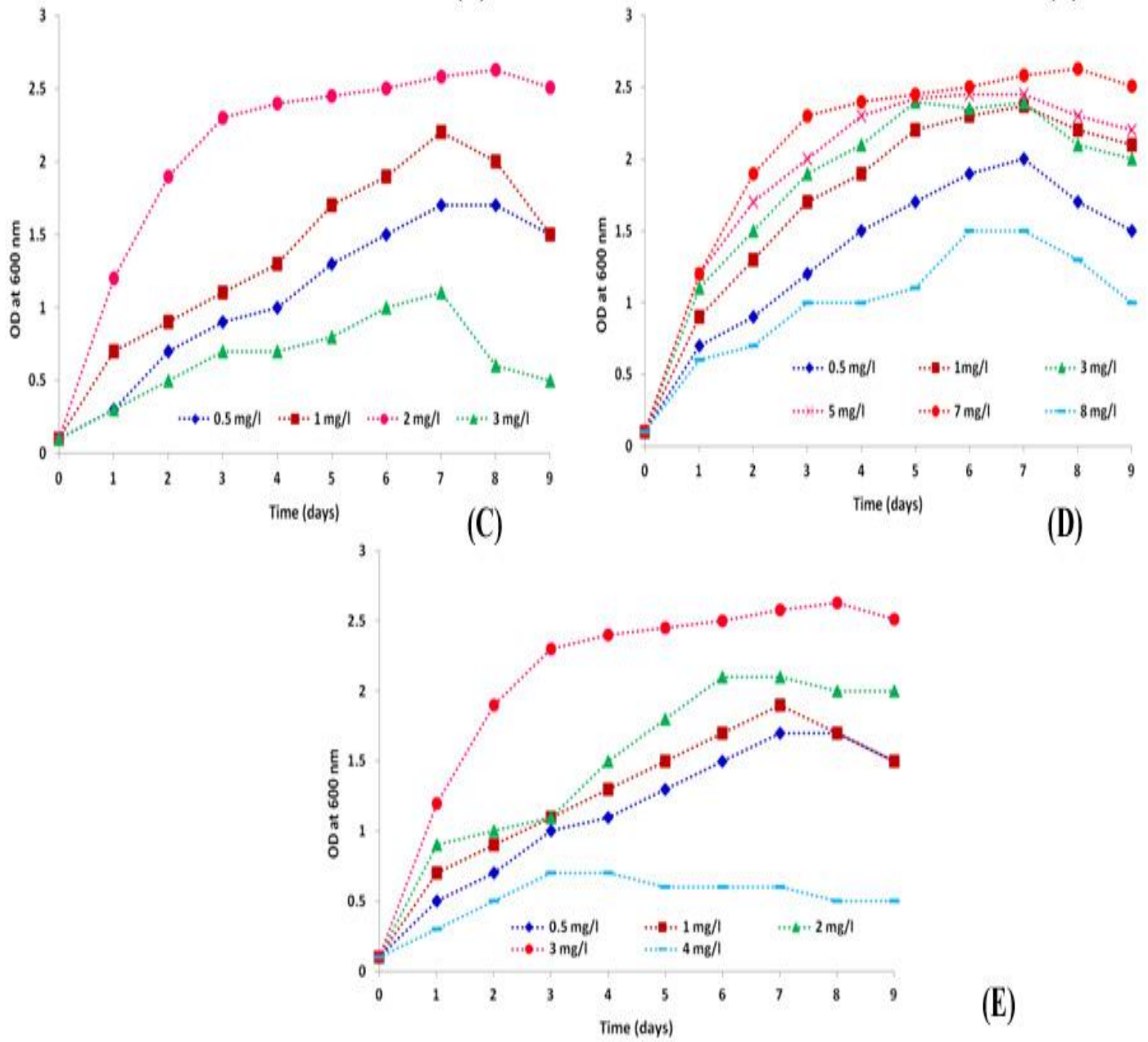

(E)

Figure 3 Effect of glucose, peptone, nitrate, phosphate, sodium chloride concentration, on the growth of Pseudomonas aeruginosa dou-1

\section{Effect of temperature with respect to time on the growth of bacteria}

Among factors limiting microbial activity, temperature is one of the most significant (Atlas and Bartha, 1993). The effect of different temperature on diesel degradation in wastewater was studied. The bacterial strain Pseudomona aeruginosa dou-1 showed optimal growth at $35^{\circ} \mathrm{C}$ (Figure. 2C). The influence of temperature on the biodegradation of diesel oil was favourable at optimum temperature of $35^{\circ} \mathrm{C}$.

\section{Effect of $\mathrm{pH}$ with respect time on the growth of bacteria}

The optimization of growth conditions showed that $\mathrm{pH} 7$ was the best for the growth of Pseudomonas aeruginosa dou-1 (Figure. 2D) and followed by $\mathrm{pH} 6$ $\mathrm{pH}$, pH8. Optimal growth of the strain Pseudomonas aeruginosa dou-1 occur at
$\mathrm{pH} 7.0$ in MMS medium with significantly higher growth was attained. Minimal growth was observed at $\mathrm{pH} 9.0$ and at $\mathrm{pH} 5.0$ (Figure. 2D).

The isolate showed an optimum growth requirement indicating that $\mathrm{pH}$ control is very important to get optimum results during bioremediation. Therefore, the optimization of environmental conditions is important for the enhancement of bacterial growth and for designing effective bioremediation strategy (Davey, 1994). The requirement of neutral or near neutrality for optimal growth of bacteria on diesel is also exhibited by many other diesel-degrading bacteria (Marquez-Rocha et al., 2005; Rajasekar et al., 2007; Kwapisz et al., 2008).

\section{Effect of glucose concentration on the growth of bacteria}

To study the effect of carbon and nitrogen sources on degradation, MMSM supplemented with $10 \%$ of diesel oil along with carbon source such as glucose and nitrogen source such peptone. The effect of different glucose concentration 
on the growth of bacterial strain for diesel degradation in wastewater showed glucose concentration of $1 \mathrm{mg} / \mathrm{l}$ gave up the optimum growth of Pseudomonas aeruginosa dou-1 (Figure.3A). Glucose served as the most favourable carbon source in comparison with sucrose and fructose. The carbon source is mainly used as a cellular constituent, and for synthesis of new cells and production of polysaccharide as an energy source.

\section{Effect of peptone concentration on the growth of bacteria}

The effect of different peptone concentration on the growth of bacterial strain for diesel degradation in wastewater confirmed that the optimal concentration that enhances the maximal growth was found to be $5 \mathrm{mg} / \mathrm{l}$ (Figure. 3B). The peptone rich of nitrogen source influence the growth and metabolism of the selected strain of Pseudomonas aeruginosa dou-1.

\section{Effect of nitrate concentration on the growth of bacteria}

The nitrogen source affects the growth and metabolic activities of the organism Various nitrogen sources such as urea, ammonium nitrate, sodium nitrate were used at an initial concentration of $1 \%(\mathrm{w} / \mathrm{v})$ in MMS media supplemented with up to $10 \%$ diesel to study their effects on bacterial growth. Sodium nitrate was observed to be the most suitable nitrogen source for the growth of the tested bacterial strain. The effect of different concentration of sodium nitrate on the growth of bacterial strain for diesel degradation in oil contaminated wastewater showed that the optimal concentration that supports maximal growth was at 2 $\mathrm{mg} / \mathrm{l}$ (Figure. 3C). Sodium nitrate was selected as the nitrogen source which can best enhance the growth of the bacteria, was chosen as the principal nitrogen source due to its widespread usage as a cheap source of nitrogen for bioremediation (Sugumar et al., 2014).

\section{Effect of phosphate concentration on the growth of bacteria}

The effect of different concentration of phosphate on diesel degradation from the oil contaminated wastewater confirmed that the optimal concentration that supports maximal growth was at $7 \mathrm{mg} / \mathrm{l}$ (Figure. 3D).

\section{Effect of salt concentration on the growth of bacteria}

The effect of different $\mathrm{NaCl}$ concentration on the growth of bacterial strain for diesel degradation in wastewater showed that increasing $\mathrm{NaCl}$ concentration in wastewater had decreasing effect on diesel degradation. The amount of oil degraded by Pseudomonas aeruginosa strain increased initially to a maximum level at $3 \mathrm{~m} / 1 \mathrm{NaCl}$, but thereafter decreased with increasing salt concentration for the substrates (Figure. 3E)

Growth and screening of oil degrading biosurfactant producing bacterial strain Pseudomonas aeruginosa dou-1 in MMSA medium at optimum condition

From the Figure.4A, the growth in terms of optical density (2.68 OD) was found to be optimum on $7^{\text {th }}$ day. Thus bacterium growth reached the stationary phase and moved into the death phase and this is probably due to the chemistry of the diesel degradation. The utilization of the diesel oil as sole carbon and energy source by the isolate resulted in the growth with a resultant production of acid. This is probably as a result of chemical change of the diesel oil, hydrocarbons and production of by products and ability of isolated Pseudomonas aeruginosa dou-1 to use diesel oil and generates organic acids. The biodegradation effectiveness of diesel oil in terms of growth by bacterial strain Pseudomonas aeruginosa dou- 1 increased in efficiency from the $1^{\text {st }}$ day to $7^{\text {th }}$ day of incubation, increasing from 1 to $10 \%$ of DO. Moreover, the growth studies indicated that diesel degradation ability was correlated with cellular growth of the organism. Almost complete removal of diesel oil (83\%) as seen after 7days of incubation. The initial $\mathrm{pH}$ of the medium used in this experiment was neutral; a decreasing trend of $\mathrm{pH}$ was detected in the experimental flasks within the incubation period, as growth increases in the presence of the diesel oil was observed (Figure.4B). A change in $\mathrm{pH}$ is largely due to the production and accumulation of bacterial waste products. Maintenance of $\mathrm{pH}$ is important since $\mathrm{pH}$ strongly affects bacterial growth (Sugumar et al., 2014).
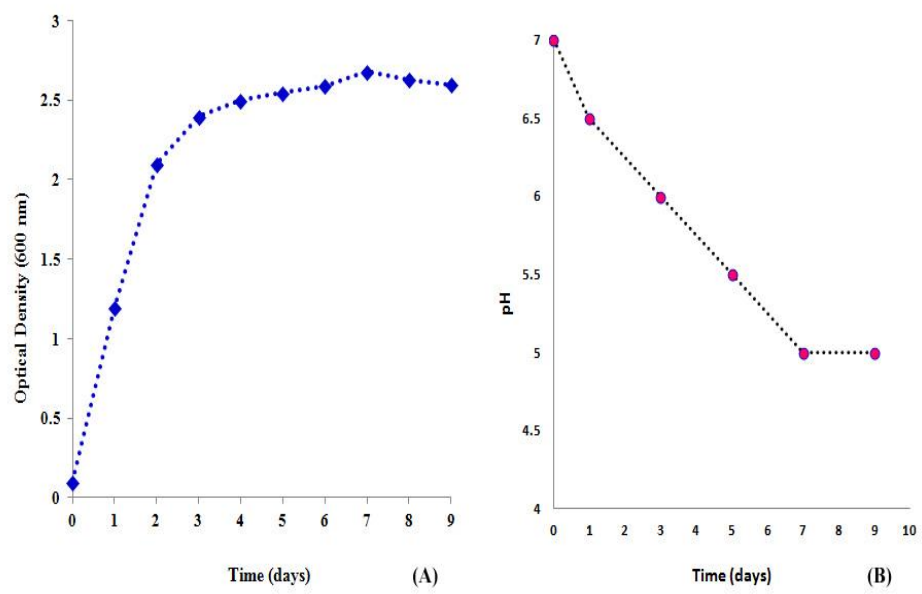

Figure 4 (A) Growth of diesel oil utilizing bacterial strain Pseudomonas aeruginosadou-1 and (B) $\mathrm{pH}$ change in culture medium (MMS) at optimized conditions after biotreatment

\section{Drop collapse method}

The bacterial strain selected out of enrichment technique in MMS agar medium was used for screening of biosurfactant production purpose. A significant biosurfactant activity was reported when Pseudomonas aeruginosa dou-1 strain was used for analysis (Table.2). Youssef $\boldsymbol{e t}$ al. (2004) stated that drop-collapse test expresses the surface activity and indicates production of biosurfactants.

\section{Oil spread method}

The study revealed a high biosurfactant activity of the bacterial strain (Pseudomonas aeruginosa dou-1) by oil spread method (Table.2). The increase in biosurfactant activity was also reported by other researchers (Ranjana Julias and Jeya Rathi, 2013).

\section{Emulsification index $\left(\mathbf{E}_{24}\right)$}

The release of biosurfactants is a strategy used by microorganisms to affect the uptake of hydrocarbon compounds (Obayori et al., 2009). Consequently, measurement of emulsification activity (E24) experiment was conducted for all of the bacteria which were successful at drop-collapse and oil spread (displacement) tests. The emulsifying capacity of the selected bacterial strain was evaluated by an emulsification index $\left(\mathrm{E}_{24}\right)$. The emulsification activity test revealed that the emulsification index $\left(\mathrm{E}_{24}\right)$ was observed to be maximum $72.72 \%$ for the diesel oil. The bacteria with emulsification indices higher than $50 \%$ have been defined as potential biosurfactant producers (Rodriguez-Rodriguez et al. 2012). This method was reported previously by many researchers in their investigations (Sugumar et al., 2004 and Grazyna et al., 2006)

Table 2 Evaluation of biosurfactant activity by drop collapse and oil spread method

\begin{tabular}{lll}
\hline Bacterial strain & Drop collapse method & Oil spread method \\
\hline $\begin{array}{l}\text { Pseudomonas aeruginosa } \\
\text { dou-1 }\end{array}$ & positive & positive \\
\hline
\end{tabular}

\section{Biodegradation efficiency}

Diesel oil degradation ability of the isolates was investigated by using both gravimetric and FTIR analysis.

\section{Gravimetric analysis of oil degradation}

Gravimetric analysis was used to determine the diesel degradation ability of the potential bacteriium and it was found to be $83 \%$ degradation by Pseudomonas aeruginosa strain (dou-1). Even though the gravimetric analysis is not as sensitive as GC analysis, it is comparatively helpful method for the preliminary determination. Therefore, the isolated bacteria found out to be successful in preceding experiments were subjected to gravimetric analysis of diesel oil degradation. The residual diesel oil amounts in samples were calculated by using the equation (2). Olsen et al. (1999) reported $75 \%$ for the n-alkane fraction of total extractable petroleum hydrocarbons in diesel oil after 35 days in batch experiments. 


\section{FTIR Analysis}

The functional group or the chemical species of the biosurfactant was examined using FTIR analysis (Figure 5). The wave number at 2955, 2924 and $2852 \mathrm{~cm}^{-1}$ indicate the $\mathrm{C}-\mathrm{H}$ stretching vibrations of hydrocarbon chain position.

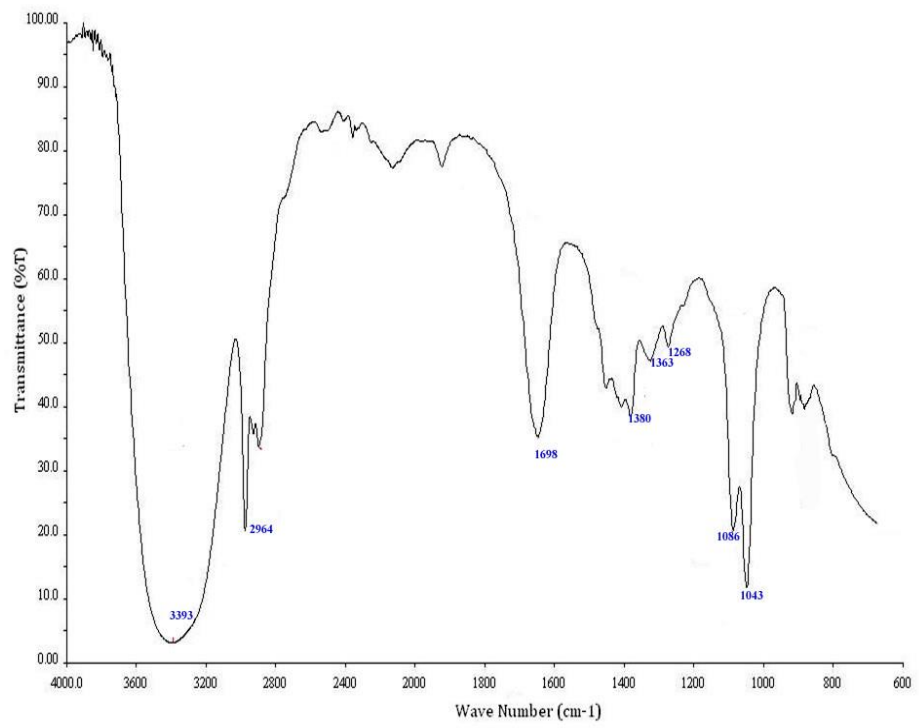

Figure 5 FTIR analysis of biosurfactant produced by the potential bacterial Pseudomonas aeruginosa dou-1

The bands at $2964 \mathrm{~cm}^{-1}$ resulting from the $\mathrm{C}-\mathrm{H}$ stretching mode indicate the fatty acid part of lipopeptide. $1268 \mathrm{~cm}^{-1}$ exhibits the $\mathrm{C}-\mathrm{N}$ stretching in peptide bond (amide III band frequency). Hydrogen bending on an aromatic ring could be observed at $800 \mathrm{~cm}^{-1}$. The wave number at $1363 \mathrm{~cm}^{-1}$ indicates the chemical structure identical to those of rhamnolipids which are composed of rhamnose rings and long hydrocarbon chains. $1268 \mathrm{~cm}^{-1}$ exhibits the $\mathrm{C}-\mathrm{N}$ stretching in peptide bond (amide III band frequency). The peaks in the range of 1080-1043 $\mathrm{cm}^{-1}$ corresponded to C-O-C stretching in the rhamnose. Similarly Pornsunthorntawee et al. (2008) and Bondarenko et al. (2010) reported similar results. The use of pure cultures in this study, in addition provides practical advantages by removing the ambiguity associated with constantly variable microbial populations (Ghazali et al., 2004). There is a possibility to increase the level of degradation by increasing the number of degradation days. The diesel oil was degraded by $P$. aeruginosa to utilize oil as the sole source of carbon and energy (Mandri and Lin, 2007). Hydrocarbon does not have any lethal effect on the growth of the bacteria. This may be due to the ability of the organisms to produce exopolysaccharises, which may protect them from the lethal effects of the hydrocarbons.

\section{CONCLUSION}

Soils contaminated with hydrocarbon are good sources for the isolation of diese oil (DO) degrading bacteria which can then be used for the elimination of such compounds from the environment. The selected bacterial strain in this study from pesticide contaminated soil was recommended that the isolates may be well adapted for use because of prior exposed and acclimatized to the xenobiotic contaminants, which can be used efficiently in bioremediation of the diesel oil contaminated sites. Screening of the isolates (Pseudomonas aeruginosa dou-1) at different $\mathrm{pH}$, temperature and agitation indicates the optimum $\mathrm{pH}$ of 7 , temperature of $35^{\circ} \mathrm{C}$ and agitation of $(150 \mathrm{rpm})$ in modified mineral salts agar medium at $10 \%$ diesel oil $(\mathrm{v} / \mathrm{v})$ with optimum concentration of additional nutrients of glucose $(1 \mathrm{mg} / \mathrm{l})$, peptone $(5 \mathrm{mg} / \mathrm{l})$, nitrate $(2 \mathrm{mg} / \mathrm{l})$, phosphate $(7$ $\mathrm{mg} / \mathrm{l})$ and sodium chloride $(3 \mathrm{mg} / \mathrm{l})$. The bioremoval and its biodegradation efficiency of Pseudomonas aeruginosa was $83 \%$ after seven days of incubation. From the study, it was concluded that the bacterial strain having the degradative potential of various pollutants include diesel oil as well as methylparathion. The bacterial strain has the ability to degrade the xenobiotic compounds practically in indigenous pure monoculture.

Acknowledgments: The author Dr. K. Usharani wishes to thank the Department of Environmental Science, Bharathiar University and also wishes to thank the editor and anonymous reviewers.

\section{CONFLICT OF INTEREST}

The authors declare no conflict of interest.

\section{REFERENCES}

ATLAS, R.M., BARTHA, R. 1972. Degradation and mineralization of petroleum in seawater limitation by nitrogen and phosphorus. Biotechnology and Bioengineering. 14: 309 -318. http://dx.doi.org/10.1002/bit.260140304

BARATHI, S., VASUDEVAN, N., 2001. Utilization of petroleum hydrocarbons by Pseudomonas fluorescens isolated from a petroleum contaminated soil. Environmental International. 413 - 416. http://dx.doi.org/10.1016/s01604120(01)00021-6

BISHNOI, N.R., KHUMUKCHAM, R., KUMAR, R., 2006. Biodegradation of pulp and paper mill effluent using anaerobic followed by aerobic digestion. Journal of Environmental Biology. 27: 405-408.

BODOUR, A. A., DREES K. P., MAIER R. M. 2003. Distribution of Biosurfactant-Producing Bacteria in Undisturbed and Contaminated Arid Southwestern Soils. Applied Environmental Microbiology. 69: 3280-3287. http://dx.doi.org/10.1128/aem.69.6.3280-3287.2003

BONDARENKO, O., RAHMAN,P.K., RAHMAN, T.J., KAHRU, A., IVASK, A. 2010. Effects of rhamnolipids from Pseudomonas aeruginosa DS10-129 on luminescent bacteria: Toxicity and modulation of cadmium bioavailability. Microbial Ecology. 59: 588-600. http://dx.doi.org/10.1007/s00248-009-9626-5

CAPPUCCINO.J., SHERMAN.N, 2010. Microbiology: A Laboratory Manual, Pearson Education, Limited, $9^{\text {th }}$ edition.

CHE, M. D. 2002. Conservative cost estimate including investigation and monitoring expenses, soil and groundwater remediation conference proceeding, Taipei.

DAVEY, K.R 1994. Review paper, modelling the combined effect of temperature and $\mathrm{pH}$ on the rate coefficient for bacterial growth. International Journal of Food Microbiology. 23: 295-303. http://dx.doi.org/10.1016/0168-1605(94)90158-9

DESAI, J.D., BANAT, I.M. 1997. Microbial Production of Surfactants and Their Commercial Potential. Microbiology and Molecuar Biology Reviews. 61(1): 4764.

EMTIAZI, G., SHAKARAMI, H. 2004. Utilization of petroleum hydrocarbons by Pseudomonas sp. and transformed Escherichia coli. African Journal of Biotechnology. 4 (2): 172-176.

ENVIRONMENTAL PROTECTION AGENCY, U.S. 1986. Test method for evaluating solid waste, SW-846, third ed., Vol. 1A. U.S. EPA, Washington, DC. GEETHA S.J., SANKET J. JOSHIA., SHAILESH KATHROTIYAB. 2013. Isolation and characterization of hydrocarbon degrading bacterial isolate from oil contaminated sites. APCBEE Procedia 5: $237-241$.

GHAZALI, F.M., RAHMAN, R.N.ZA, SALLEH, A.B., BASRI, M. 2004 Degradation of hydrocarbons in soil by microbial consortium. International Journal of Biodeterioration Biodegradation. 54(1): 61-67. http://dx.doi.org/10.1016/j.ibiod.2004.02.002

GHOSH, J., TICK, G. R. 2013. A pore scale investigation of crude oil distribution and removal from homogeneous porous media during surfactant induced Remediation, Journal of Contaminant Hydrology.155: 20-30. http:// doi: 10.1016/j.jconhyd.2013.09.003.

GRAŻYNA A. PŁAZA, IRENEUSZ ZJAWIONY, IBRAHIM M. BANAT 2006. Use of diferent methods for detection of thermophilic biosurfactan producing bacteria from hydrocarbon contaminated and bioremediated soils. Journal of Petroleum Science and Engineering. 2006, 50 (1): 71-77. http://dx.doi.org/10.1016/j.petrol.2005.10.005

HAGWELL, I.S., DELFINO, L.M., RAO, J.J. 1992. Partitioning of Polycyclic Aromatic Hydrocarbons from oil into water. Environmental Science and Technology. 26: 2104-2110. http://dx.doi.org/10.1021/es00035a005

HARAYAMA, S, KISHIRA, H, KASAI, Y, SHUTSUBO, K. 1999. Petroleum biodegradation in marine environments. Journal of Molecular Microbiology and Biotechnology. 1:63-70.

HOLT, J. G., KRIEG, N. R., SNEATH, P. H. A., STALEY, J. T., WILliAMS S. T. 1994. Bergey's manual of determinative bacteriology, 9th. Edn. Williams \& Wilkins, Baltimore, USA.

HONG, J.H., KIM, J., CHOI, O.K., CHO, K.S., RYU, H.W. 2005 Characterization of a diesel-degrading bacterium, Pseudomonas aeruginosa IU5, isolated from oil-contaminated soil in Korea. World Journal of Microbiology and Biotechnology. 21: 381-384. http//: DOI 10.1007/s11274-004-3630-1

JACOBS, C.J., PRIOR, B.A. DEKOCK, M.J. 1983. A rapid screening method to detect ethanol production by microorganisms. Journal of Microbiological Methods.1: 339-342. http://dx.doi.org/10.1016/0167-7012(83)90010-6

KWAPISZ, E., WSZELAKA, J., MARCHUT, O., BIELECKI, S. 2008. The effect of nitrate and ammonium ions on kinetics of diesel oil degradation by Gordonia alkanivorans S7. International Journal of Biodeterioration and Biodegradation. 61(3): 214-222. http://dx.doi.org/10.1016/j.ibiod.2007.08.002

LEADBETTER, E.R., FOSTER, J.W. 1958. Studies of some methane utilizing $\begin{array}{llll}\text { bacteria. Archives of Microbiology. } & 30(1): & 91- & 118\end{array}$ http://dx.doi.org/10.1007/bf00509229

LEE, M., KIM, M.K., SINGLETON, I., GOODFELLOW, M., LEE, S.T. 2006 Enhanced biodegradation of diesel oil by a newly identified Rhodococcus baikonurensis EN3 in the presence of mycolic acid. Jornal of Applied Microbiology. 100(2): 325- 333. http//: doi:10.1111/j.1365-2672.2005.02756.x. 
MANDRI, T, LIN, J. 2007. Isolation and Characterization of Engine Oil Degrading Indigenous Microorganisms in KwaZulu-Natal, South Africa, African Journal of Biotechnology. 6(1) : 23-27.

MARQUEZ-ROCHA, F.J., HERNANDEZ-RODRIGUEZ, V., LAMELA, M.T 2001. Biodegradation of diesel oil in soil by a microbial consortium, Water Air Soil Pollution. 128: 313-320. http://dx.doi.org/10.1023/a:1010392821353

MARQUEZ-ROCHA, OLMOS-SOTO, F.J.J., CONCEPCION ROSANO HERNANDEZ, M., MURIEL-GARCIA, M. 2005. Determination of the hydrocarbon-degrading metabolic capabilities of tropical bacterial isolates. International Journal of Biodeterioration and Biodegradation. 55: 17-23. http://dx.doi.org/10.1016/j.ibiod.2004.05.007

MISHRA S, JYOT,J., KUHAD,R.C.., LAL, B. 2001. Evaluation of inoculum addition to stimulate in situ Bioremediation of oily sludge contaminated soil. Applied Environmental Microbiology. 67(4): 1675-1681. http://dx.doi.org/10.1128/aem.67.4.1675-1681.2001

MORIKAWA M, HIRATA Y, IMANAKA T. 2000. A study on the structurefunction relationship of lipopeptidebiosurfactants. Biochimica et Biophysica Acta. 1488(3): 211-218. http://dx.doi.org/10.1016/s1388-1981(00)00124-4

MUKHERJI, S., JAGADEVAN, S., MOHAPATRA, G., VIJAY, A. 2004 Biodegradation of diesel oil by an Arabian Sea sediment culture isolated from the vicinity of an oil field. Bioresource Technology. 95: 281-286. http://dx.doi.org/10.1016/j.biortech.2004.02.029

OBAYORI, O.S., ILORI, M.O., ADEBUSOYE, S.A., OYETIBO, G.O. OMOTAYO, A.E., AMUND, O.O. 2009. Degradation of hydrocarbons and biosurfactant production by Pseudomonas sp. strain LP1. World Journal of Microbiology and Biotechnology. 25:1615-1623. http://dx.doi.org/10.1007/s11274-009-0053-z

OLSON, J.J., MILLS, G.L., HERBERT, B.E., MORRIS, P.J., 1999. Biodegradation rates of separated diesel components. Environmental Toxicology and Chemistry. 18: 2448-2453. http://dx.doi.org/10.1002/etc.5620181110

PORNSUNTHORNTAWEE O., WONGPANIT P., CHAVADEJ S., ABE M. AND RUJIRAVANIT R., 2008. Structural and physicochemical characterization of crude biosurfactant produced by Pseudomonas aeruginosa SP4 isolated from petroleum-contaminated soil. Bioresource Technology. 99(6):1589-1595. http://dx.doi.org/10.1016/i.biortech.2007.04.020

RAHMAN, K.S.M., RAHMAN, T., LASKHMANAPERMALSAMY, P., BANAT, I.M. 2002. Occurrence of crude oil degrading bacteria in gasoline and diesel station soils. Journal of Basic Microbiology. 4: 286293.

jobm284>3.0.co:2-m http://dx.doi.org/10.1002/1521-4028(200208)42:4<284::aid-

RAJASEKAR, A., BABU, T.G., PANDIAN, S.T., MARUTHAMUTHU, S. PALANISWAMY N., RAJENDRAN, A. 2007. Role of Serratia marcescen ACE2 on diesel degradation and its influence on corrosion. Journal of Industrial $\begin{array}{llll}\text { Microbiology and } & \text { Biotechnology. } & 34(9): & 589-598\end{array}$ http://dx.doi.org/10.1007/s10295-007-0225-5

RANJANA JULIASTHILAKAR., JEYA RATHI, J., 2013. Bioremediation of diesel contaminated soil by oil degrading bacteria (Pseudomonas $\mathrm{sp}$ ) using biostimulation method. Journal of Microbiology and Biotechnology Research. 3(5): 18-26

RODRIGUEZ-RODRIGUEZ，C., CAROLINA，Z., CAROLINA， B. 2012. Evaluation of growth in diesel fuel and surfactants production ability by bacteria isolated from fuels in Costa Rica. Revista de la Sociedad Venezolana de Microbiología. 32:116120.

SAADOUN, I. 2002. Isolation and characterization of bacteria from crude petroleum oil contaminated soil and their potential to degrade diesel fuel. Journal of Basic Microbiology. 42:420 - 428. http//:doi: 10.1002/1521 4028(200212)42:6<420::AID-JOBM420>3.0.CO;2-W

SATPUTE, S.K., BHAWSAR, B.D., DHAKEPHALKAR, P.K., CHOPADE, B.A. 2008.Assessment of different screening methods for selecting biosurfactan producing marine bacteria. Indian Journal of Marine Science. 37(3): 243-250.

SHUKOR, M.Y., HASSAN, N.A.A., JUSOH, A.Z., PERUMAL, N., SHAMAAN,N.A., MACCORMACK, W.P., SYED, M.A. 2009. Isolation and characterization of a Pseudomonas diesel-degrading strain from Antarctica Journal of Environmental Biology. 30(1): 1-6.

SUGUMAR, S., GHOSH, V., NIRMALA, M.J., MUKHERJEE, A., CHANDRASEKARAN, N., 2014. Ultrasonic emulsification of eucalyptus oil nanoemulsion: antibacterial activity against Staphylococcus aureus and wound healing activity in Wistar rats. Ultrasonics Sonochemistry. 21(3): 10441049 .

UENO A., ITO, Y, YUMOTO, I, OKUYAMA, H, 2007. Isolation and characterization of bacteria from soil contaminated with diesel oil and the possible use of these in autochthonous bioaugmentation. World Journal of Microbiology and Biotechnology. 23:1739-1745. http://doi:10.1007/s11274 007-9423-6

YEUNG, P.Y., JOHNSON, R.L., XU, J. G. 1997. Biodegradation of petroleum hydrocarbons in soil as affected by heating and forced aeration, Journal of Environmental Quality. 26(6): $1511-1516, \quad 1997$. http://doi:10.2134/jeq1997.00472425002600060009x.

YOUSSEF, N.H., DUNCAN, K.E., NAGLE, D.P., SAVAGE, K.N., KNAPP R.M., MICHAEL, J.M. 2004. Comparison of methods to detect biosurfactant production by diverse microorganisms. Journal of Microbiological Methods. 56(3): 339-347. http://dx.doi.org/10.1016/i.mimet.2003.11.001 